\section{Managing Apple Crop Load and Diseases with Bloom Thinning Applications in an Organically Managed 'Honeycrisp'/'MM.111' Orchard}

\author{
Gregory M. Peck ${ }^{1}$ \\ Horticulture Section, School of Integrative Plant Science, Cornell University, \\ 121 Plant Science Building, Ithaca, NY 14853
}

Candace N. DeLong, Leon D. Combs, and Keith S. Yoder

Alson H. Smith, Jr. Agricultural Research and Extension Center, Virginia Polytechnic Institute and State University, 595 Laurel Grove Road, Winchester, VA 22602

Additional index words. apple scab, cedar apple rust, Japanese knotweed, liquid lime sulfur, powdery mildew, quince rust

\begin{abstract}
Although demand for organic produce continues to increase in the midAtlantic, few apple (Malus $\times$ domestica Borkh.) growers in the region have adopted organic management practices due to the considerable disease, insect, and weed pressure, as well as the lack of effective crop load management tools. In this study, lime sulfur (LS) and Regalia ${ }^{\circledR}(R)$ were applied in different sequences (i.e., LS/LS, LS/R, $R / R$, and $R / L S$ ), each in a mixture with JMS Stylet-Oil, to chemically thin apple flowers in an organically managed 'Honeycrisp'/'MM.111' orchard. There was also a nontreated control, a "grower standard" control (LS at $11 \mathrm{~mm}$ fruitlet diameter), and a hand-thinned control. The treatments were evaluated for their ability to reduce crop load, as well as to control powdery mildew [Podosphaera leucotricha (EIlis \& Everh.) E. S. Salmon], cedar apple rust (Gymnosporangium juniperi-virginiana Schwein.), and quince rust (Gymnosporangium clavipes Cooke \& Peck). All treatments reduced crop load compared with the nontreated control, and after the first application of LS or R, the number of fertilized king blooms was reduced and fertilization was prevented in all side blooms. All bloom thinning treatments had more fruit peel russet than the control and russet was more severe when LS was one of the applications. Bloom thinning applications of LS and R did not reduce powdery mildew leaf infection compared with the nontreated control. Cedar apple rust incidence was reduced by all bloom thinning treatments, though some lesions were detected in all treatments. There were minimal quince rust infections in any of the treatments, including the nontreated control. These results suggest that when LS and/or Regalia ${ }^{\circledR}$ are mixed with JMS Stylet-Oil and applied as bloom thinners, they can reduce crop load, and, as a secondary benefit, they can also decrease cedar apple rust incidence from infections that occur during bloom.
\end{abstract}

Received for publication 3 Oct. 2016. Accepted for publication 11 Jan. 2017.

Funding support was provided by a U.S. Department of Agriculture-Specialty Crop Block Grant administered by the Virginia Department of Agriculture and Consumer Services, Virginia Agricultural Experiment Station, and Virginia Tech's Department of Horticulture.

We thank Sierra Athey, Matt Borden, David Carbaugh, Allen Cochran II, Scott Kilmer, Abby Kowalski, Taylor Mackintosh, Jared Repass, William Royston, Jr., Ashley Thompson, and Jim Warren for their assistance with this experiment. Mention of a trademark, proprietary product, or vendor does not constitute a guarantee or warranty of the product by the authors and does not imply its approval to the exclusion of other products or vendors that also may be suitable.

${ }^{1}$ Corresponding author. E-mail: gmp32@cornell. edu.
There is a need to conduct research specifically for organic apple (Malus $\times$ domestica) production in the mid-Atlantic region (including the states of Delaware, Maryland, New Jersey, North Carolina, Pennsylvania, Virginia, and West Virginia), so that local growers can supply the increasing demand for organic products. In 2015, organic product sales exceeded $\$ 43$ billion in the United States, of which produce accounted for $13 \%$ of the total sales (Organic Trade Association, 2016). However, under the current U.S. Department of Agriculture-National Organic Program (USDA-NOP) regulations, growing apples organically in the eastern United States can be challenging due to the lack of effective biological, cultural, or chemical controls for the immense insect, disease, and weed pressure experienced in this region (Cromwell et al.,
2011; Peck et al., 2010; Williams et al., 2016). Additionally, crop load management options are limited in organic production because the USDA-NOP prohibits the use of the synthetically derived plant growth regulators that are used for this purpose in conventional systems (U.S. Department of Agriculture, 2016).

Managing crop load in apple orchards is essential for improving fruit size and color, preventing broken limbs due to the excess weight of fruit, and ensuring adequate return bloom to minimize biennial bearing (Byers, 2003; Dennis, 2000). Thinning, or reducing the number of apples per tree and within each fruiting cluster, can also decrease disease pressure by allowing for more rapid drying conditions within fruit clusters and allowing for more complete spray coverage of the developing fruitlets. Thinning during bloom may increase these benefits and decrease the likelihood of biennial bearing cycles by eliminating excess fruit before flower bud initiation occurs (Batjer and Hoffman, 1951; Greene, 2002).

In the experiment described in this paper, we evaluated bloom thinning materials applied according to output from a 'Honeycrisp'-specific pollen tube growth model for their ability to reduce crop load and disease incidence. The pollen tube growth model uses hourly temperature data to predict the amount of time between pollination and fertilization (Peck et al., 2016; Yoder et al., 2013). This information is then used to allow a preset percentage of flowers to set fruit, while fertilization in later blooming flowers is prevented by treatment (most commonly liquid LS) with a chemical that kills the pollen tubes before they fertilize additional eggs.

Liquid LS tank mixed with oil (either fish or a petroleum-based product) is a recommended chemical combination for apple bloom thinning under organic management in the eastern United States (Peck and Merwin, 2010). However, before OR-CAL, Inc. (Junction City, OR) changed the label on Rex Lime Sulfur Solution in 2015, LS was only legally approved for bloom thinning and for use with oil in Washington State (Lehnert, 2014). Additionally, LS is caustic and often causes fruit russeting, therefore reducing the value of the fruit (Peck et al., 2010). Other negative impacts of LS result from its phytotoxicity, which disrupts photosynthesis, and thus potentially yield, tree growth, and return bloom (Holb et al., 2003; McArtney et al., 2006). Additionally, LS can be a very potent bloom thinner and may over thin the crop in some years. For these reasons, additional bloom thinning product options are needed for use in the eastern United States.

In prior tests, the biofungicide, Regalia ${ }^{\circledR}$ (Marrone Bio Innovations, Inc., Davis, CA), made from the extracts of Giant Knotweed [Reynoutria sachalinensis (F. Schmidt) Nakai syn. Polygonum sachalinense (F. Schmidt)], was found to function as an apple bloom thinner (Peck et al., 2016; Yoder et al., 2013). Our interest in the product began after observing damaged petals in an apple disease control field experiment where Regalia ${ }^{\circledR}$ was applied during bloom. We hypothesized that the 
product was caustic and potentially damaging to other floral organs. The disease control efficacy of Regalia ${ }^{\circledR}$ is reported to be from a unique mechanism of induced plant resistance that upregulates chalcone synthase and chalcone isomerase in the phenylpropanoid pathway and induces the production and accumulation of phytoalexins (Su et al., 2012). In a previous formulation, named Milsana ${ }^{\circledR}$ (Marrone Bio Innovations, Inc.), $R$. sachalinensis extracts were shown to decrease powdery mildew infection on cucumbers, tomatoes, begonias, and wheat (Daayf et al., 1995; Dik and van der Staay, 1995; Herger et al., 1988; Herger and Klingauf, 1990; KonstantinidouDoltsinis et al., 2006; Konstantinidou-Doltsinis and Schmitt, 1998). Regalia ${ }^{\circledR}$ is currently labeled for use as a fungicide on many horticultural and agronomic crops, but its mode of action as a bloom thinner is unknown.

Among the many fungal diseases that require grower intervention in the mid-Atlantic, cedar apple rust (G. juniperi-virginiana) and quince rust ( $G$. clavipes) are formidable barriers to organic apple production because they are not effectively controlled by organically approved fungicides such as sulfur and copper (Yoder et al., 2006). An experimental formulation of $R$. sachalinensis (MOI-106020) that was tested before the commercial release of Regalia ${ }^{\circledR}$ was found to provide cedar apple rust control (Halbrendt et al., 2010). Similarly, prior tests in Virginia indicated that control of rusts by a combination of Regalia ${ }^{\circledR}$ and JMS Stylet-Oil (JMS Flower Farms, Inc., Vero Beach, FL) provides effective control of cedar apple rust and after-infection control of quince rust (Peck et al., 2016; Yoder et al., 2015). Thus, we saw an opportunity to target two of the key barriers for organic apple production in the mid-Atlantic, namely reliable crop load and disease management.

The objective of this project was to test the disease control achieved while using different sequences of LS and/or Regalia ${ }^{\circledR}$, each in combination with JMS Stylet-Oil, for bloom thinning. We hypothesized that these bloom thinning materials would aid disease control in an organically managed apple orchard.

\section{Materials and Methods}

The study was conducted in an 8-year-old 'Honeycrisp'/‘MM.111' apple orchard located at Virginia Tech's Alson H. Smith, Jr. Agricultural Research and Extension Center in Winchester, VA $\left(39^{\circ} 06^{\prime} \mathrm{N}, 78^{\circ} 17^{\prime} \mathrm{W}\right)$. Trees were spaced $3 \mathrm{~m}$ between trees and $7 \mathrm{~m}$ between rows. In 2015, the year of this experiment, only USDA-NOP approved products were applied to the orchard (Table 1). Before 2015, all trees had been managed conventionally. A row of border trees on the west side of the block, as well as four trees on each end of each row with treatment trees were not sprayed for the entire season. The experiment was conducted on the remaining four rows.

Treatments were applied at the dilute rate to the point of runoff with a single nozzle handgun at $1723 \mathrm{kPa}$. Maintenance sprays were applied with an airblast sprayer (Swanson Model DA-400; Durand-Wayland, LaGrange, GA) calibrated to deliver 935 $\mathrm{L} \cdot \mathrm{ha}^{-1}$. Weeds were managed by using Suppress Herbicide EC (Westbridge Agricultural Products, Vista, CA) at $28.3 \mathrm{~L}$ of product in 467.2 L of water/ha on 23 May and 4 July. Full bloom occurred on $25 \mathrm{Apr}$. and petal fall occurred on 4 May.

Average style length and hourly temperature data were used in a 'Honeycrisp' specific pollen tube growth model to determine treatment application timing (Yoder et al., 2013). On 20 Apr., 50 king bloom flowers were randomly collected from the sample branches and used to measure style length using a millimeter ruler. Temperature data were obtained from a weather station (Campbell Scientific ET106, Logan, UT) located $\approx 350 \mathrm{~m}$ from the apple trees used in this experiment.

Each of the four bloom thinning treatments consisted of two separate applications: LS (Miller Chemical \& Fertilizer Corp., Hanover, PA) followed by LS (LS/LS), LS followed by Regalia ${ }^{\circledR}$ (Marrone Bio Innovations) (LS/R), Regalia ${ }^{\circledR}$ followed by LS (R/ LS), and Regalia ${ }^{\circledR}$ followed by Regalia ${ }^{\circledR}$ (R/ $\mathrm{R})$. Bloom thinning rates were held constant at $18.8 \mathrm{~L}$ of liquid LS or $9.4 \mathrm{~L}$ of Regalia ${ }^{\circledR}$ and were mixed with $9.4 \mathrm{~L}$ of JMS Stylet-Oil (JMS Flower Farms, Inc.) at each application. A nontreated control, an organic "grower standard" bloom thinning treatment of $18.8 \mathrm{~L}$ of liquid LS with 9.4 L of JMS Stylet-Oil applied when average fruitlet diameter was $10.7 \mathrm{~mm}$ (LSfruitlet), and a hand-thinned treatment were also included in the experimental design.

Three king bloom flowers and three side bloom flowers per block (12 total) were collected $24 \mathrm{~h}$ after the first application of LS or Regalia ${ }^{\circledR}$. Flower samples were stored in a $5 \%$ sodium sulfite (Amresco, Solon, $\mathrm{OH}$ ) solution at $4{ }^{\circ} \mathrm{C}$ to halt pollen tube growth until histological examination as described by Embree and Foster (1999). Briefly, flowers were prepared for visualization by boiling in the sodium sulfite solution for $15 \mathrm{~min}$ to soften tissues. Carpels were then excised and pressed between two microscope slides with a water-soluble solution of $0.01 \%$ aniline blue (MP Biomedicals, LLC, Solon, OH) stain in $0.067 \mathrm{M}$ $\mathrm{K}_{2} \mathrm{HPO}_{4}$. Slides were then held in a dark cabinet for $24 \mathrm{~h}$. Flower organs were visualized using a compound microscope (Nikon Optiphot, Melville, NY) at $\times 100$ magnification with a high-pressure mercury vapor epi-ultraviolet light source (Zeiss HBO50; Osram GmbH, Augsburg, Germany). Flowers were considered fertilized if at least one pollen tube reached the base of the style.

Two branches per tree were assessed on 3 June for crop load [number of fruit $/ \mathrm{cm}^{2}$ branch cross-sectional area (BCSA)]. Disease incidence was rated on 10 shoots per replicate tree on 12 Aug. Leaf nodes were counted on each shoot, and missing leaves at each node position for the first 20 nodes were recorded. Fruit size and russet ratings were taken on 25 fruit per experimental unit on 20 Aug. Fruit peel russeting was evaluated by estimating the percent area affected on individual fruit. Fruit were rated U.S. Fancy or U.S. Extra Fancy if less than $15 \%$ of the surface area was russeted (U.S. Department of Agriculture, 2002).

Each treatment consisted of four singletree replications in a completely randomized block design. Blocking was based on bloom density ratings that were recorded before the first treatment application in 2015. Statistical analysis was completed using analysis of variance (PROC ANOVA, SAS Institute Inc., Cary, NC), and post hoc mean separations were determined by Tukey's Honestly Significant Difference or the Waller-Duncan K-ratio $t$ test. Flower fertilization data were arcsine square root

Table 1. Organic fungicides and insecticides applied to the 'Honeycrisp'/'MM.111' apple orchard used for a bloom thinning experiment in 2015.

\begin{tabular}{|c|c|c|c|c|}
\hline Date & Fungicides (rate/ha) & Target disease & Insecticides (rate/ha) & Target insect \\
\hline 18 Apr. (Pink) & Cueva 9.4 L + Double Nickel LC 2.3 L & Scab, fire blight & - & - \\
\hline 6 May (Petal fall) & Cueva $9.4 \mathrm{~L}+$ Double Nickel $2.3 \mathrm{~L}$ & Scab, fire blight & $\begin{array}{l}\text { Entrust SC } 0.6 \mathrm{~L}+\text { Pyganic } \\
\text { EC1.4L 2.9 L }\end{array}$ & $\begin{array}{l}\text { Codling moth }(\mathrm{CM}), \\
\text { oriental fruit moth }(\mathrm{OFM}), \\
\text { plum curculio }(\mathrm{PC})\end{array}$ \\
\hline 20 May & Microthiol Disperss $9 \mathrm{~kg}$ & Powdery mildew & Madex HP $0.1 \mathrm{~L}+$ Deliver $0.5 \mathrm{~kg}$ & CM, OFM, leaf rollers (LR) \\
\hline 27 May & Microthiol Disperss $9 \mathrm{~kg}$ & Powdery mildew & Madex HP $0.1 \mathrm{~L}+$ Deliver $0.5 \mathrm{~kg}$ & $\begin{array}{l}\text { LR, brown marmorated } \\
\text { stink bug (BMSB) }\end{array}$ \\
\hline 6 June & Microthiol Disperss $9 \mathrm{~kg}$ & Powdery mildew & Deliver $0.5 \mathrm{~kg}+$ Pyganic $1.5 \mathrm{~L}$ & LR. BMSB, Japanese beetle (JB) \\
\hline 18 June & Microthiol Disperss $9 \mathrm{~kg}$ & Powdery mildew & Deliver $0.5 \mathrm{~kg}+$ Pyganic $1.5 \mathrm{~L}$ & CM, OFM, JB \\
\hline 1 July & Cueva 4.7 L + Double Nickel $2.3 \mathrm{~L}$ & Summer diseases & $\begin{array}{l}\text { Entrust SC } 0.6 \mathrm{~L}+\text { Madex } \\
\quad \text { HP } 0.1 \mathrm{~L}+\text { Deliver } 0.5 \mathrm{~kg}+\end{array}$ & $\mathrm{CM}$, OFM, JB, apple maggot (AM \\
\hline 15 July & Cueva 4.7 L + Double Nickel 2.3 L & Summer diseases & Deliver $0.5 \mathrm{~kg}$ & CM, OFM \\
\hline 31 July & Cueva 4.7 L + Double Nickel 2.3 L & Summer diseases & Entrust SC $0.6 \mathrm{~L}+$ Pyganic $2.3 \mathrm{~L}$ & OFM, AM, JB \\
\hline 6 Aug. & Cueva 4.7 L + Double Nickel 2.3 L & Summer diseases & _ & - \\
\hline
\end{tabular}


transformed before analysis, but are presented as untransformed means.

\section{Results}

A visual assessment of flowering in 2015 ranged between $20 \%$ and $30 \%$ of the greatest amount of flowering in that block. There were not enough trees with greater bloom density to use in the experiment. The 'Honeycrisp' pollen tube growth model was started at $1000 \mathrm{HR}$ on 20 Apr. and thinning treatments were applied at 0800 HR on 27 Apr. and at 1600 HR on 29 Apr. (Fig. 1). The nontreated control had an average of 6.8 fruit $/ \mathrm{cm}^{2}$ BCSA (Table 2). All treatments reduced crop load compared with the nontreated control, and there were no differences in crop load among the treatments. Only the LS/LS treatments did not have greater fruit mass at harvest than the nontreated control. The LS/LS treatment had less fruit mass and smaller fruit diameter than the R/R and LSfruitlet treatments (the grower standard treatment), but had similar fruit size to the other treatments.

All four bloom thinning treatments had greater fruit russet ratings and less fruit in the U.S. Fancy or Extra Fancy grades than the nontreated control, LSfruitlet, and handthinned treatments, which all had similar levels of russet (Table 2). Among the four bloom thinning treatments, $\mathrm{R} / \mathrm{R}$ had the lowest fruit russet rating and the most fruit in the U.S. Fancy and Extra Fancy grades.

The $\mathrm{R} / \mathrm{R}$ treatment had greater return bloom (measured as the percent of spurs with flowers) in 2016 than the nontreated control, LS/LS, R/LS, LSfruitlet, and hand-thinned treatments, but was similar to the $\mathrm{LS} / \mathrm{R}$ treatment (Table 2). Apart from the $\mathrm{R} / \mathrm{R}$ treatment, the return bloom was very low and 2016 would be considered an "off year" in the biennial bearing cycle for this orchard.

Ninety-two percent of the nontreated control king flowers were fertilized, whereas $67 \%$ and $50 \%$ of the king flowers were fertilized after the first treatments of LS and Regalia $^{\circledR}$, respectively (Fig. 2). Twenty-five percent of the side bloom flowers on control trees were fertilized, whereas none of side bloom flowers were fertilized on trees treated with LS or Regalia ${ }^{\circledR}$.

As indicated by the incidence of powdery mildew and cedar apple rust on the nontreated control trees, the test orchard had substantial levels of both diseases (Table 3). The hand-thinned treatment had a greater percentage of leaves with powdery mildew infection than the nontreated control, $\mathrm{R} / \mathrm{R}$, and LSfruitlet treatments. The percent of leaves infected with powdery mildew ranged from $10 \%$ to $22 \%$, and was statistically greater for the hand-thinned treatment than the LS/LS, R/R, R/LS, and LSfruitlet treatments. The percent of leaves with cedar apple rust infection was greater on control and hand-thinned trees compared with all of the chemical thinning treatments (Table 3 ). The LSfruitlet treatment had less cedar apple rust lesions than the nonsprayed treatments. Minimal quince rust infection was recorded in this experiment and there were no treatment differences (data not shown). The four bloom thinning treatments had similar disease incidence.

The number of leaves per shoot was the same among treatments (Table 3). The LS/LS and the R/LS treatments resulted in a greater percent of defoliation in the first 20 leaves, compared with the control, R/R, and handthinned treatments.

\section{Discussion}

The overall goal of this study was to determine if LS and Regalia ${ }^{\circledR}$, applied for bloom thinning, could sufficiently reduce crop load, as well as powdery mildew, cedar

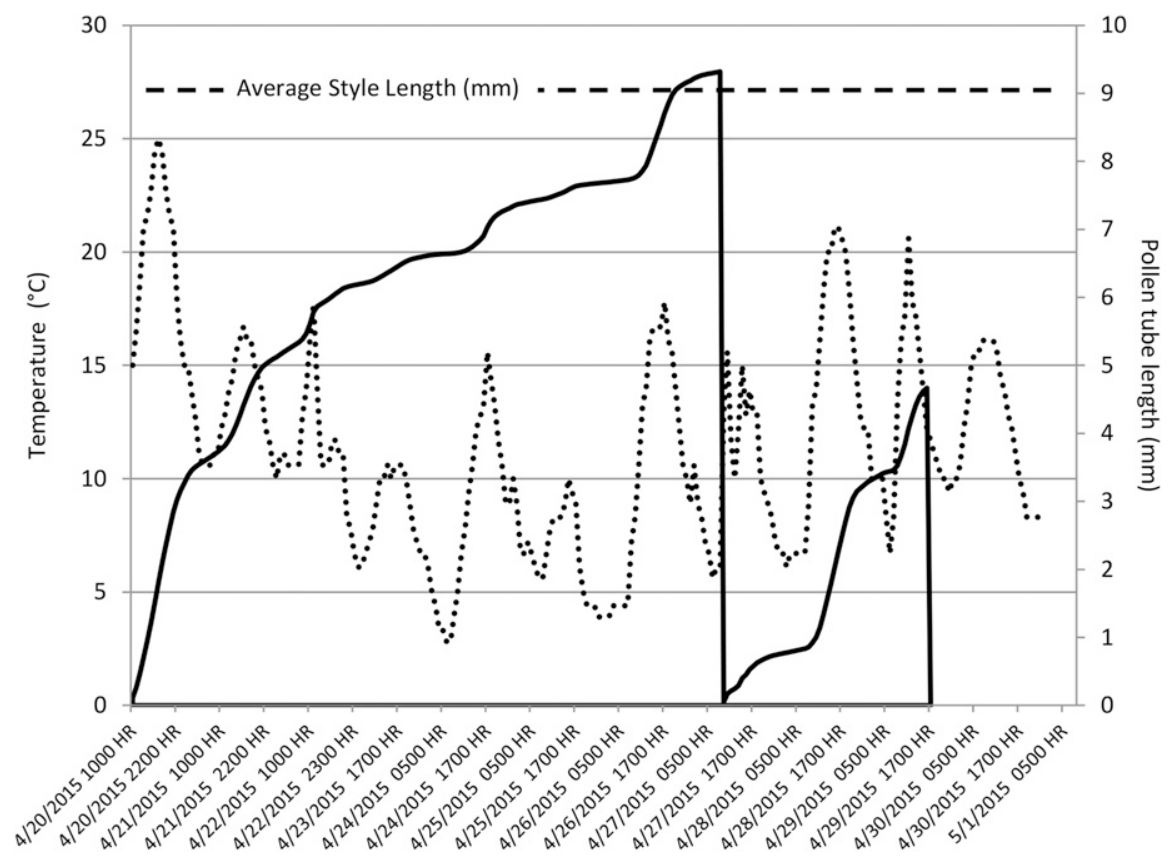

Fig. 1. Graphical representation of the 'Honeycrisp'-specific apple pollen tube growth model from 2015. Hourly temperature data (dotted line) were collected from a weather station located near the experimental orchard and cumulative pollen tube growth (solid line) was calculated on an hourly basis. Average style length (dashed line) was $9.0 \mathrm{~mm}$, as measured on 50 king bloom flowers on 20 Apr. Bloom thinning treatments were applied at $0800 \mathrm{HR}$ on 27 Apr. and $1600 \mathrm{HR}$ on 29 Apr. Cumulative pollen tube growth was reset to $0 \mathrm{~mm}$ after each application.

Table 2. Crop load, fruit mass and diameter, fruit finish $(0=$ no visible russet; $5=$ severe russet), fruit above U.S. Fancy and Extra Fancy grades for russet, and 2016 return bloom (percentage of visible spurs with flowers) from successive applications of lime sulfur (LS) and/or Regalia ${ }^{\circledR}$ used during bloom in an organically managed 'Honeycrisp'/'MM.111' apple orchard in 2015.

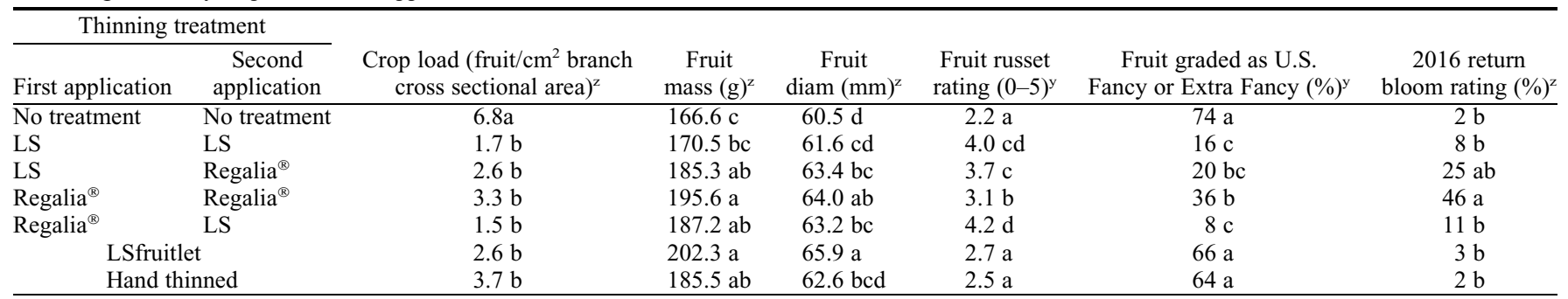

All bloom thinning applications were mixed with JMS Stylet-Oil. There was also a nontreated control, a "grower standard" control (LS mixed with JMS StyletOil applied at 11-mm fruitlet diameter; LSfruitlet), and a hand-thinned control. Bloom thinning applications occurred on 27 Apr and 29 Apr. and were based on a 'Honeycrisp'-specific, temperature-based pollen tube growth model, the grower standard application occurred on 11 May, and hand thinning occurred between 3 and 5 June.

${ }^{\mathrm{z}}$ Mean separation within column by Tukey's Honestly Significant Difference.

${ }^{\mathrm{y}}$ Waller-Duncan K-ratio $t$ test $(P=0.05)$ using four single-tree replications. 
apple rust, and quince rust infections, in an organically managed apple orchard. We evaluated blossom thinning chemicals as the only fungicide sprays applied during bloom. All of the chemical thinning treatments that we tested reduced crop load and cedar apple rust infection compared with the nontreated control. Regalia $^{\circledR}$ and LS, when applied with JMS Stylet-Oil, provided similar bloom thinning results to each other, matching our previous research focused on bloom thinning applications when these materials were applied with the spreader/sticker Latron B-1956 (Yoder et al., 2013). As a bloom thinner, the mode of action for Regalia ${ }^{\circledR}$ is unknown, but our study suggests that Regalia ${ }^{\circledR}$ may inhibit fertilization by damaging floral organs. Similar to LS, Regalia ${ }^{\circledR}$ inhibited pollen tubes from reaching the base of the style and fertilizing the egg in side bloom flowers (Fig. 2). Although our experiment does not explain why Regalia ${ }^{\circledR}$ is caustic, we do provide evidence that Regalia ${ }^{\circledR}$ can reliably be used for bloom thinning in conjunction with the pollen tube growth model.

All chemical thinning treatments in this study would be considered "over thinned" (too few fruit) in a commercial setting; however, the 'Honeycrisp' block used in this experiment had low levels of bloom at the start of the project. The nontreated control treatment had 6.8 fruit $/ \mathrm{cm}^{2}$ BCSA, while the target crop load for mature 'Honeycrisp'/ 'MM.111' trees is $\approx 5$ fruit $/ \mathrm{cm}^{2}$ BCSA indicating the amount of thinning needed initially in this orchard block was minimal (Robinson et al., 2009). The chemical thinning treatments used in this experiment may not "over thin" in years when flower density is greater.

Treatments of LS applied on 29 Apr. (when the maximum temperature was $24^{\circ} \mathrm{C}$ )

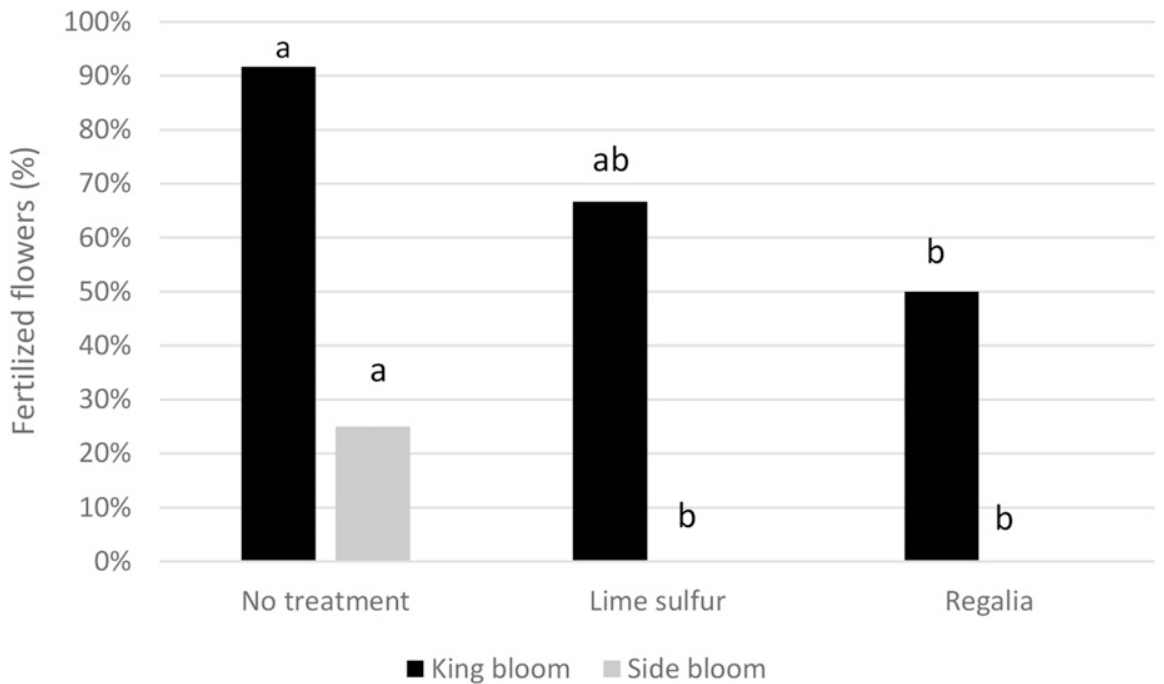

Fig. 2. The percent of king and side apple flowers that were fertilized $24 \mathrm{~h}$ after the first bloom thinning applications of lime sulfur or Regalia ${ }^{\circledR}$ (both applied with JMS Stylet-Oil) on 27 Apr. Fertilization was determined visually using fluorescence microscopy by determining whether pollen tubes reached the base of the style. Mean separation within king or side bloom by Tukey's honestly significant difference $(P=0.05)$. Data were arcsine square root transformed before analysis, but means $(\mathrm{n}=4)$ are shown untransformed. resulted in lower crop load and higher fruit russet ratings than those of Regalia ${ }^{\circledR}$ treatments applied on the same day. LS is known to be phytotoxic and may result in several undesirable side effects, including increased russet and reduced photosynthesis, especially when applied during warmer temperatures (Holb et al., 2003; Hyre, 1939; McArtney et al., 2006; Palmer et al., 2003). Our results indicate Regalia ${ }^{\circledR}$ can be applied during bloom with lower phytotoxicity risk than LS.

Our study also suggests that selective use of Regalia ${ }^{\circledR}$ and JMS Stylet-Oil could decrease cedar apple rust infection in organic orchards. Cedar apple rust infection periods occurred on 14-15 Apr., 30 Apr. to 1 May, 12 May, 5-6 May, and 6-7 May. These infections were most likely suppressed by the bloom thinning treatments applied on 27 and 29 Apr. Thus, the cedar apple rust suppression may have been achieved by a combination of $13 \mathrm{~d}$ of postinfection activity (from 14 to $27 \mathrm{Apr}$.) and up to $8 \mathrm{~d}$ of protectant action (29 Apr. to 6-7 May). The findings in the present study support those of a previous study that showed postinfection suppression of quince rust by Regalia ${ }^{\circledR}$ mixed with JMS Stylet-Oil in a conventionally managed orchard (Yoder et al., 2015). However, timing fungicide applications according to the bloom thinning pollen tube growth model may miss cedar apple rust infection periods in some years and commercial apple growers should base crop load and disease management decisions on the specific conditions in their orchard each year. Furthermore, the LSfruitlet treatment in our study resulted in less cedar apple rust infection than the control and hand-thinned treatments suggesting that a later fungicide application timing may have had greater efficacy.

Bloom thinning applications of LS and Regalia ${ }^{\circledR}$ did not reduce mildew percent infection compared with the nontreated control (Table 3). However, border trees with no chemical pest control applications had $64 \%$ of leaves infected with mildew, compared with an average of $16 \%$ of leaves infected on treatment trees. Thus, while Su et al. (2012)

Table 3. Powdery mildew (Podosphaera leucotricha) and cedar apple rust (Gymnosporangium juniperi-virginiana) incidence and the mean number of leaf nodes and the percent of missing leaves within the first 20 leaf nodes on the assessed branches after successive applications of lime sulfur (LS) and/or Regalia ${ }^{\circledR}$ used during bloom in an organically managed 'Honeycrisp'/'MM.111' apple orchard in 2015.

\begin{tabular}{|c|c|c|c|c|c|c|c|}
\hline \multirow{2}{*}{\multicolumn{2}{|c|}{ Thinning treatment }} & \multicolumn{4}{|c|}{ Foliar diseases } & \multirow{2}{*}{ Leaf nodes/shoot (no.) } & \multirow{2}{*}{ Missing leaves/shoot (\%) } \\
\hline & & \multicolumn{2}{|c|}{ Powdery mildew } & \multicolumn{2}{|c|}{ Cedar apple rust } & & \\
\hline LS & Regalia $^{\circledR}$ & $18 \mathrm{bc}$ & $3 a b$ & $15 \mathrm{bc}$ & $0.3 \mathrm{ab}$ & 25 & $5 \mathrm{~b}$ \\
\hline Regalia $^{\circledR}$ & Regalia $^{\circledR}$ & $14 \mathrm{ab}$ & $2 \mathrm{a}$ & $13 \mathrm{ab}$ & $0.3 \mathrm{ab}$ & 24 & $2 \mathrm{a}$ \\
\hline Regalia $^{\circledR}$ & LS & $15 \mathrm{abc}$ & $2 \mathrm{a}$ & $14 a b$ & $0.3 \mathrm{ab}$ & 25 & $10 \mathrm{c}$ \\
\hline \multicolumn{2}{|c|}{ Hand thinned } & 64 & 19 & 37 & 1.4 & 26 & 1 \\
\hline
\end{tabular}

All bloom thinning applications were mixed with JMS Stylet-Oil. There was also a nontreated control, a "grower standard" control (LS mixed with JMS StyletOil applied at 11-mm fruitlet diameter; LSFruitlet), and a hand-thinned control. Bloom thinning applications occurred on 27 Apr. and 29 Apr. and were based on a 'Honeycrisp'-specific, temperature-based pollen tube growth model, the grower standard application occurred on 11 May, and hand thinning occurred between 3 and 5 June. Border trees were not treated with any thinning or pest control materials for the entire season, were not part of the replicated experiment, and thus the data from these trees are provided only as a reference point to show the amount of disease pressure in the orchard.

${ }^{\mathrm{z}}$ Mean separation within column by Waller-Duncan K-ratio $t$ test $(P=0.05)$ using four single-tree replications and ten shoots per replication. 
reported that $R$. sachalinensis extracts reduced powdery mildew infection (as well as, several bacterial and other fungal diseases) on other horticultural crops, more research is needed to understand the circumstances (e.g., application timing and rate) that would lead to greater control of apple powdery mildew with Regalia ${ }^{\circledR}$ and other products with a similar a.i. and/or mode of action. Additionally, although there were nearly 3 weeks between the application of the second bloom thinning treatments and the elemental sulfur sprays, treatment differences in our study may not have been evident due to the elemental sulfur applications on all treatments during the early summer, which would have protected the trees and fruit from powdery mildew infection. Future studies should extend the time between the bloom thinning applications and other fungicides to determine if greater control can be achieved.

Through our results, we provide evidence that bloom thinning sprays of LS and Regalia ${ }^{\circledR}$ in combination with JMS Stylet-Oil can reduce crop load and decrease cedar apple rust infection. Thus, bloom thinning with these materials could also provide disease control, potentially reducing the need for at least one postbloom fungicide cover spray and leading to an overall reduction in the volume of chemicals used in an organic apple orchard. At an average cost of $\$ 100 / \mathrm{ha} / \mathrm{yr}$ for a fungicide application (including material, labor, and machinery), reducing fungicide applications would have a direct economic impact on orchard profitability (Peck et al., 2010). Additionally, the use of two Regalia ${ }^{\circledR}$ applications instead of two LS applications reduced fruit russet down-grading by more than $50 \%$, which would also result in increased profitability. However, timing of fungicide applications should not be completely contingent on the criteria being used for bloom thinning applications, and commercial growers should not assume that bloom thinning applications with LS or Regalia $^{\circledR}$ will control cedar apple rust in years when infection periods occur much later than anthesis. Conversely, growers should be aware that bloom-time applications of LS or Regalia ${ }^{\circledR}$ for disease control can damage flowers and potentially reduce yields. In conclusion, our findings indicate that LS and the biofungicide, Regalia ${ }^{\circledR}$, in combination with JMS Stylet-Oil, could provide after-infection control of cedar apple rust, reduce crop load, and possibly result in an overall reduction in the number of required chemical sprays.

\section{Literature Cited}

Batjer, L.P. and M.B. Hoffman. 1951. Fruit thinning with chemical sprays. U.S. Dept. Agr. Circ. 867, Washington, DC.

Byers, R.E. 2003. Flower and fruit thinning and vegetative: Fruiting balance. In: D.C. Ferree and I.J. Warrington (eds.). Apples: Botany, production and uses. CABI Publishing, Cambridge, MA.

Cromwell, M.L., L.P. Berkett, and H.M. Darby. 2011. Alternative organic fungicides for apple scab management and their non-target effects. HortScience 46:1254-1259.

Daayf, F., A. Schmitt, and R.R. Belanger. 1995. The effects of plant extracts of Reynoutria sachalinensis on powdery mildew development and leaf physiology of long English cucumber. Plant Dis. 79:577-580.

Dennis, F.G. 2000. The history of fruit thinning. Plant Growth Regulat. 31:1-16.

Dik, A.J. and M. van der Staay. 1995. The effects of Milsana ${ }^{\circledR}$ on cucumber powdery mildew under Dutch conditions. Med. Fac. Landbouww. Rijksuniv. Gent. 59:1027-1039.

Greene, D.W. 2002. Chemicals, timing, and environmental factors involved in thinner efficacy on apples. HortScience 37:477-481.

Embree, C.G. and A. Foster, Jr. 1999. Effects of coatings and pollenicides on pollen tube growth through the stigma and style of 'McIntosh' apple blossoms. J. Tree Fruit Prod. 2:19-32.

Halbrendt, N.O., J.W. Travis, and B. Jarjour. 2010. Evaluation of organic fungicide programs for apple scab, powdery mildew, and cedar apple rust, 2009. Plant Dis. Mgt. Rpt. 4:PF011. Online publication. doi: 10.1094/PDMR04.

Herger, G., F. Klingauf, D. Mangold, E.H. Pommer, and M. Scherer. 1988. Efficacy of extracts of Reynoutria sachalinensis (F. Schmidt) Nakai (Polygonaceae) against fungal diseases, especially powdery mildews (in German). Nachrichtenblatt des Deutschen Pflanzenschutzdienstes (Braunschweig) 40:56-60.

Herger, G. and F. Klingauf. 1990. Control of powdery mildew fungi with extracts of the giant knotweed, Reynoutria sachalinensis (Polygonaceae). Med. Fac. Landbouww Rijksuniv Gent. 55:1007-1014.

Holb, I.J., P.F. DeJong, and B. Heijne. 2003. Efficacy and phytoxicity of lime sulfur in organic apple production. Ann. Appl. Biol. 142:225-233.

Hyre, R.A. 1939. The effect of sulfur sprays on the photosynthesis and transpiration of apple leaves. N.Y. Agr. Expt. Sta. Mem. 222.

Konstantinidou-Doltsinis, S. and A. Schmitt. 1998. Impact of treatment with plant extracts from Reynoutria sachalinensis (F. Schmidt) Nakai on disease severity of powdery mildew and yield in cucumber under Greek conditions. Crop Prot. 17:649-656.

Konstantinidou-Doltsinis, S., E. Markellou, A.M. Kasselaki, M.N. Fanouraki, C.M. Koumaki, A. Schmitt, A. Liopa-Tsakalidis, and N.E. Malathrakis. 2006. Efficacy of Milsana ${ }$, a formulated plant extract from Reynoutria sachalinensis, against powdery mildew of tomato (Leveillula taurica). BioControl 51:375392.

Lehnert, R. 2014. Pollen tube growth model makes thinning more precise. Good Fruit Grower. 19 Mar. 2014. <http://www.goodfruit.com/pollen-tube-growth-model-makesthinning-more-precise/ $>$.

McArtney, S., J. Palmer, S. Davies, and S. Seymour. 2006. Effects of lime sulfur and fish oil on pollen tube growth, leaf photosynthesis and fruit set in apple. HortScience 41:357-360.

Organic Trade Association. 2016. 2016 Organic industry survey. Organic Trade Association, Washington, DC.

Palmer, J.W., S.B. Davies, P. Shaw, and J.N. Wünsche. 2003. Growth and fruit quality of 'Braeburn' apple trees as influenced by fungicide programmes suitable for organic production. N. Z. J. Crop Hort. Sci. 31:169-177.

Peck, G.M., I.A. Merwin, M.G. Brown, and A.M. Agnello. 2010. Integrated and organic fruit production systems for 'Liberty' apple in the Northeast USA: A systems-based evaluation. HortScience 45:1038-1048.

Peck, G.M. and I.A. Merwin. 2010. A grower's guide to organic apples. NYS IPM Publication No. 223. Geneva, NY.

Peck, G.M., L.D. Combs, C.N. DeLong, and K.S. Yoder. 2016. Precision apple flower thinning using organically-approved chemicals. Acta Hort. 1137:47-52.

Robinson, T., S. Lopez, K. Iungerman, and G. Reginato. 2009. Crop load management for consistent production of Honeycrisp apples. NY Fruit Quart. 17:24-28.

Su, H., R. Blair, T. Johnson, and P. Marrone. 2012. Regalia $^{\circledR}$ bioprotectant in plant disease management. Outlooks on Pest Mgt. 23:30-34.

U.S. Department of Agriculture. 2002. United Stated standards for grades of apples. U.S. Dept. Agr. Agricultural Mktg. Serv., Washington, DC.

U.S. Department of Agriculture. 2016. Organic regulations. U.S. Dept. Agr. Natl. Organic Program, Washington, DC. 31 Aug. 2016. <http:// www.ams.usda.gov/rules-regulations/organic/>.

Williams, M.A., J.G. Strang, R.T. Bessin, D. Law, D. Scott, S. Witt, and D.D. Archibold. 2016. An assessment of organic apple production in Kentucky. HortTechnology 25:154-161.

Yoder, K.S., A.E. Cochran, II, W.S. Royston, Jr., and S.W. Kilmer. 2006. Broad-spectrum disease management by certified organic and home fruit fungicides, 2005. F\&N Tests 61:PF019. $31 \mathrm{Aug}$. 2016. <http://www.plantmanagementnetwork. org/pub/trial/fntests/reports/2006/PF019.pdf $>$.

Yoder, K.S., G.M. Peck, L.D. Combs, and R.E. Byers. 2013. Using a pollen tube growth model to improve apple bloom thinning for organic production. Acta Hort. 1001:207-214.

Yoder, K.S., A.E. Cochran, II, W.S. Royston, Jr. and S.W. Kilmer. 2015. After-infection control of quince rust on Red Delicious and Golden Delicious apples, 2014. Plant Disease Mgt. Rpt 9:PF015. 31 Aug. 2016. <http://www. plantmanagementnetwork.org/pub/trial/PDMR/ reports/2015/PF015.pdf $>$. 